\title{
ON THE NATURE OF SVALBARD ICEBERGS
}

\author{
By Julian A. Dowdeswell
}

(Department of Geography, University College of Wales, Aberystwyth, Dyfed SY23 3DB, Wales)

ABSTRACT. The nature of icebergs calved from Svalbard's $1030 \mathrm{~km}$ of tide-water ice cliffs is related to glacier dynamics and morphology. Both iceberg dimensions and rates of relative iceberg production are affected. Valley tide-water glaciers entering fjords typically calve irregular icebergs of $<50 \mathrm{~m}$ in length. Ice caps and large outlet glaciers, which predominate in eastern Svalbard, yield small, irregular icebergs and large ( $>500 \mathrm{~m}$ length) tabular icebergs which can travel considerable distances before melting. Surge-type ice masses calve very large numbers of small icebergs during short periods of rapid advance, but few icebergs during longer periods of stagnation and retreat between surges. The nature of iceberg interactions with sea ice also influences the timing and pattern of iceberg production. Winter shore-fast ice traps icebergs close to tide-water ice cliffs. They are released as a pulse on spring-time fast-ice break-up. Pack ice damps waves, and therefore increases iceberg stability and reduces the frequency of overturn. Small icebergs of ten undergo complete melting and sediment release within fjords. Larger icebergs can be trapped close to glacier termini by shallow bedrock or morainic sills, but some larger, tabular icebergs do escape into the Barents Sea. Implications for iceberg rafting of sediments include the production of large numbers of relatively debris-rich icebergs during surges and the absence of floating ice masses. The latter restricts the loss of debris-rich basal ice by undermelt prior to calving.

\section{INTRODUCTION}

Icebergs are calved from the tide-water margins of Svalbard glaciers and ice caps, which extend for over $1000 \mathrm{~km}$ around the archipelago. This paper aims to investigate the control that the dynamic regime and dimensions of parent ice masses have on the size, shape, and relative rate of production of calved icebergs.

We examine, for the area around the Svalbard archipelago (Fig. 1), the nature of icebergs calved from different types of ice mass. These include tide-water valley glaciers, which generally flow within steep-sided fjords, and larger ice caps and outlet glaciers which terminate in long sections of vertical ice cliffs which are more open to the ocean. In addition, ice masses of both types have been observed to undergo periodic surges (Liestøl, 1969; Schytt, 1969), and the dynamic differences between surging and either quiescent or non-surging Svalbard glaciers requires a third category for discussion. For each type of ice mass, observations at the tide-water margins of one or more glaciers are described. The general implications of these observations for (i) the relative rates of iceberg production, and (ii) the dimensions of the calved icebergs, are then discussed. We also investigate the nature of iceberg interactions with sea ice for icebergs of different size calved into varying oceanographic settings. The implications of these findings for glacimarine sedimentation are also discussed briefly. Svalbard provides an appropriate regional context for this study for two reasons. First, its ice masses exhibit considerable variations in their scale and dynamics. Secondly, contrasting topographic settings, oceanographic and sea ice conditions are found on its east and west coasts.

\section{BACKGROUND}

Tide-water ice masses fringe significant parts of the major islands within the Svalbard archipelago (Fig. 1; Table I). The distribution of these tide-water ice cliffs provides a fundamental control on the source and occurrence of icebergs around Svalbard. In total, almost $20 \%$ of the coastline is composed of ice cliffs. This represents an interface of about $1030 \mathrm{~km}$ where glaciers meet marine waters, and along which iceberg calving may take place. However, the distribution of these areas is not uniform and is related to the distribution of glacierized land in the archipelago (Fig. 1; Table I). There is a general decline from north-east to west in the proportion of tide-water termini relative to total coastal length. For example, Kvitøya and Storøya in eastern Svalbard are fringed along 92 and $41 \%$ of their coasts respectively by ice cliffs, whereas the western island of Prins Karls Forland has only $8 \%$ ice cliffs (Table I).

Comparison with the length of tide-water ice-mass margins in the Canadian Arctic islands illustrates the importance of iceberg-producing coastline in Svalbard. Ellesmere and Devon Islands are the only two islands with over $100 \mathrm{~km}$ of ice-cliff coast, and on Devon Island only about $150 \mathrm{~km}$ of the coast is composed of ice cliffs (Inland Waters Branch, 1969). Axel Heiberg Island and Baffin Island have only approximately 10 and $70 \mathrm{~km}$ of tide-water ice margins, respectively.

Previous reports concerning icebergs in the Svalbard region are sparse, and relate mainly to the Barents Sea, east of the archipelago. The scattered observations of flat-topped, tabular icebergs by early explorers and scientists have been summarized by Sandford (1955) for the area between Svalbard and Zemlya Frantsa Iosifa. Tabular icebergs were only sporadically noted, and these were suggested to have been derived mainly from the tide-water ice masses of Zemlya Frantsa Iosifa. Vinje (1985) reported that visua sightings over a number of years in the Barents Sea indicate that most icebergs are less than $100 \mathrm{~m}$ in length. The thickness of 59 icebergs around Svalbard and Zemlya Frantsa Iosifa was calculated by Voevodin (1972) from observations of their freeboard and assumptions concerning their density. Modal values for underwater thickness were $20-30$ and $10-20 \mathrm{~m}$, respectively, for icebergs from the two areas, and calculated maximum keel depths reached between 50 and $60 \mathrm{~m}$. Iceberg keels of between 90 and $100 \mathrm{~m}$ depth are implied by the presence of recent plough marks on the floor of the north-west Barents Sea, identified using side-scan sonar methods (Elverhøi and Solheim, 1983).

\section{DATA SOURCES AND METHODS}

In this paper, observations of Svalbard icebergs come from three sources. The first is the comprehensive collection of oblique and vertical aerial photographs held at the Norsk Polarinstitutt. Oblique photographs of tide-water ice masses date back to 1936 and 1938 , while vertical photographs at $1: 17000$ and 1:50000 scales are available for dates in the 1960 s and 1970s. Almost the entire archipelago is covered at least once and of ten a number of times. 


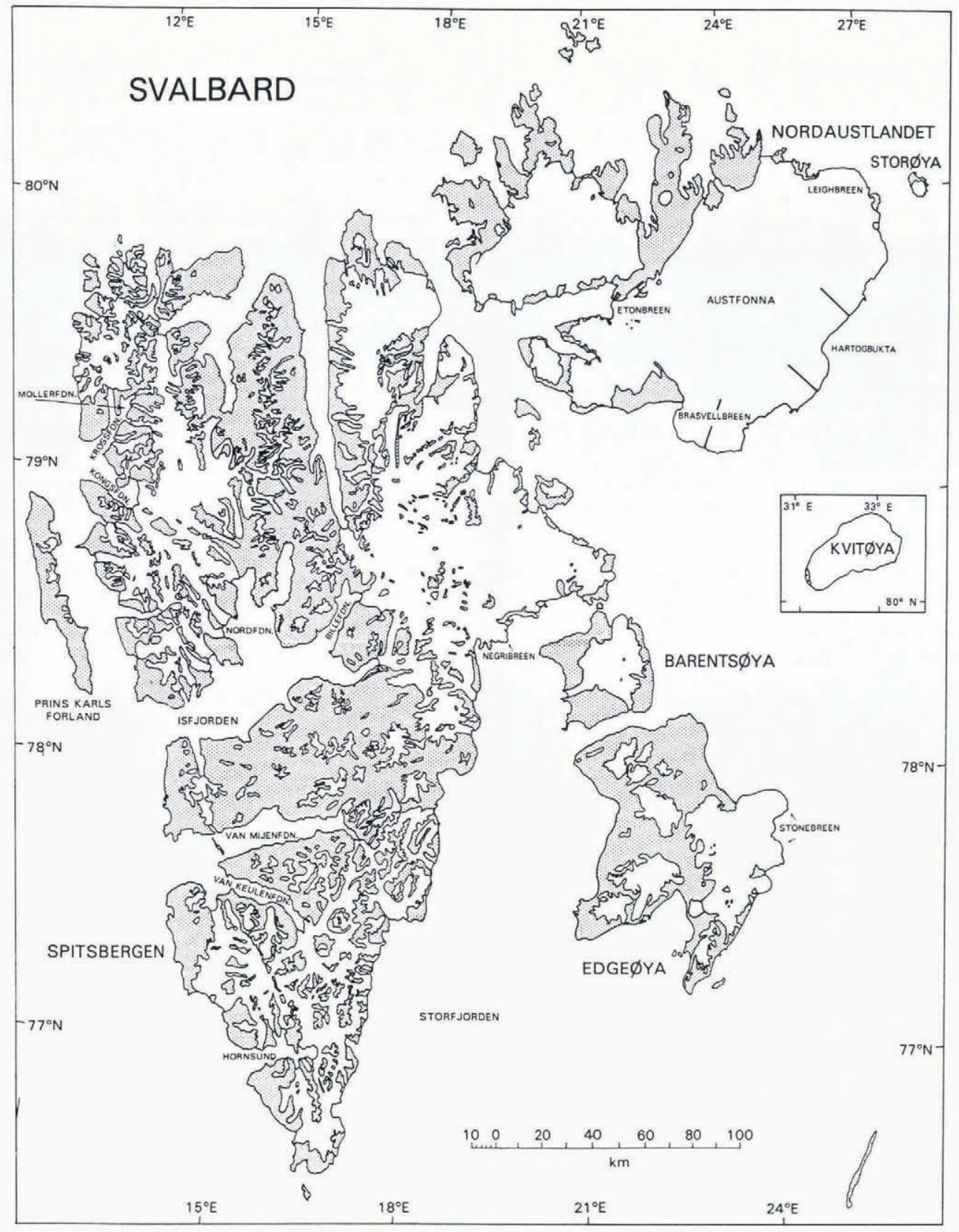

Fig. 1. Map of Svalbard (with non-glacierized land shaded), indicating the distribution of tide-water ice masses around the coastline. Kvitoya is east of Nordaustlandet, at lat. $80^{\circ} 15^{\prime} \mathrm{N}$., long. $32^{\circ} \mathrm{E}$. Locations of the radio echo-sounding profiles from Nordaustlandet shown in Figure 6 are indicated.

TABLE I. THE LENGTH OF ICE CLIFFS PROVIDING A SOURCE FOR ICEBERGS ON THE MAIN ISLANDS OF SVALBARD

Island

Total coast Length ice Ice cliffs as length cliffs \% of coast

$\begin{array}{lrrr}\text { Spitsbergen } & 3068 & 484 & 16 \\ \text { Nordaustlandet } & 1369 & 306 & 22 \\ \text { Edgeøya } & 429 & 79 & 18 \\ \text { Prins Karls Forland } & 208 & 17 & 8 \\ \text { Barentsøya } & 186 & 23 & 12 \\ \text { Kvitøya } & 115 & 106 & 92 \\ \text { Storøya } & 32 & 13 & 41 \\ \text { Totals } & 5407 & 1028 & 19\end{array}$

The second and third data sources derive from flights over much of Svalbard in 1980, 1983, 1986, and 1987, covering all of the major islands in the archipelago in over $10000 \mathrm{~km}$ of flight track. This work obtained a comprehensive network of glacier-thickness and surfacealtimetric data using airborne $60 \mathrm{MHz}$ radio echo-sounding (RES) equipment (Dowdeswell and others, 1984, 1986; Drewry and Liestøl, 1985). These geophysical data provide information on terminal ice thickness and, therefore, on the maximum possible thickness of calved icebergs. Several displays of radio echo-sounding data are presented, which are constructed from the time delay of returned echoes from the ice surface and glacier bed, and converted to ice thickness using a velocity of radio waves in ice of

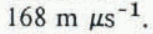

Visual observations and photographs taken on these radio echo-sounding flights, and on cruises in the archipelago, provide a third form of less systematic evidence concerning Svalbard icebergs. All airborne radio echosounding flights were carried out in late April and early May, and this gave the opportunity to observe winter conditions where fast ice was still present in an unbroken sheet in many fjords and sheltered coastal areas. These observations complement summer aerial photographs from the Norsk Polarinstitutt collection. 


\section{ICEBERGS CALVED FROM TIDE-WATER VALLEY GLACIERS}

Valley glaciers ending in tide water are most common in the fjords of western and northern Spitsbergen, but also occur in other areas of the archipelago (Figs 1 and 2). The termini of these glaciers can be subdivided into two major types. First, there are relatively active glaciers in which heavy crevassing is present. Ice-surface velocities of $0.7 \mathrm{~m} \mathrm{~d}^{-1}$ for Hansbreen in Hornsund, and up to $6 \mathrm{~m} \mathrm{~d}^{-1}$ in summer for Kongsvegen in Kongsfjorden have been observed (Meier and Post, 1987), although the value for Kongsvegen is unusually high. Secondly, there are relatively more stagnant glaciers whose tide-water margins are relatively crevasse-free. A number of these tide-water glaciers may be in the quiescent phase between periodic

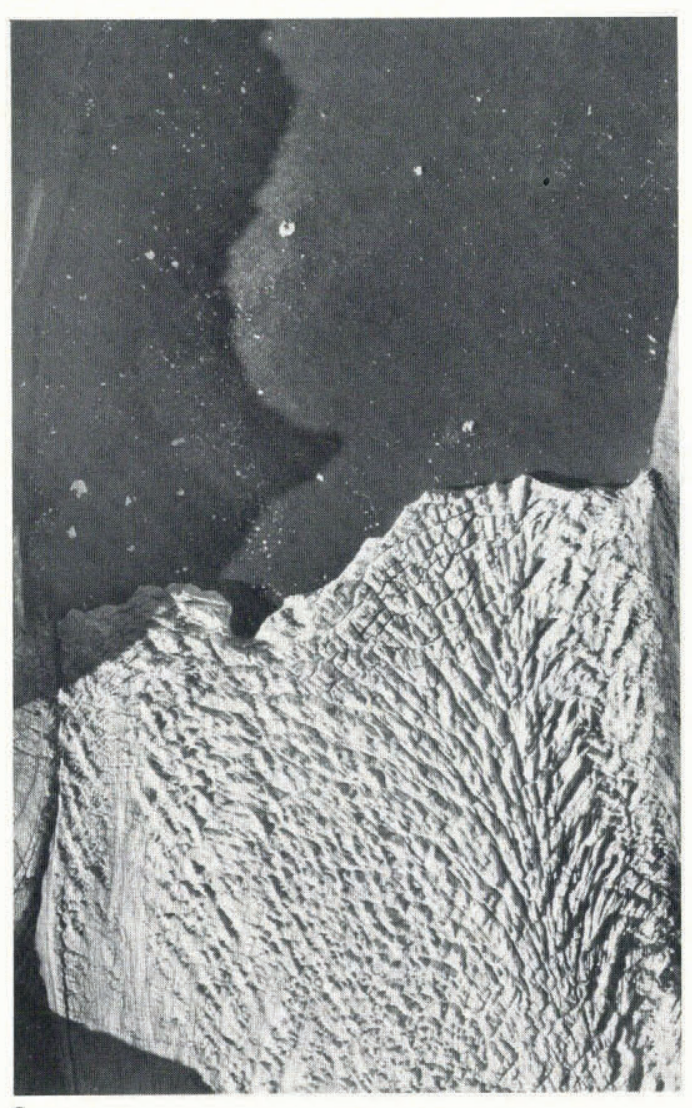

a

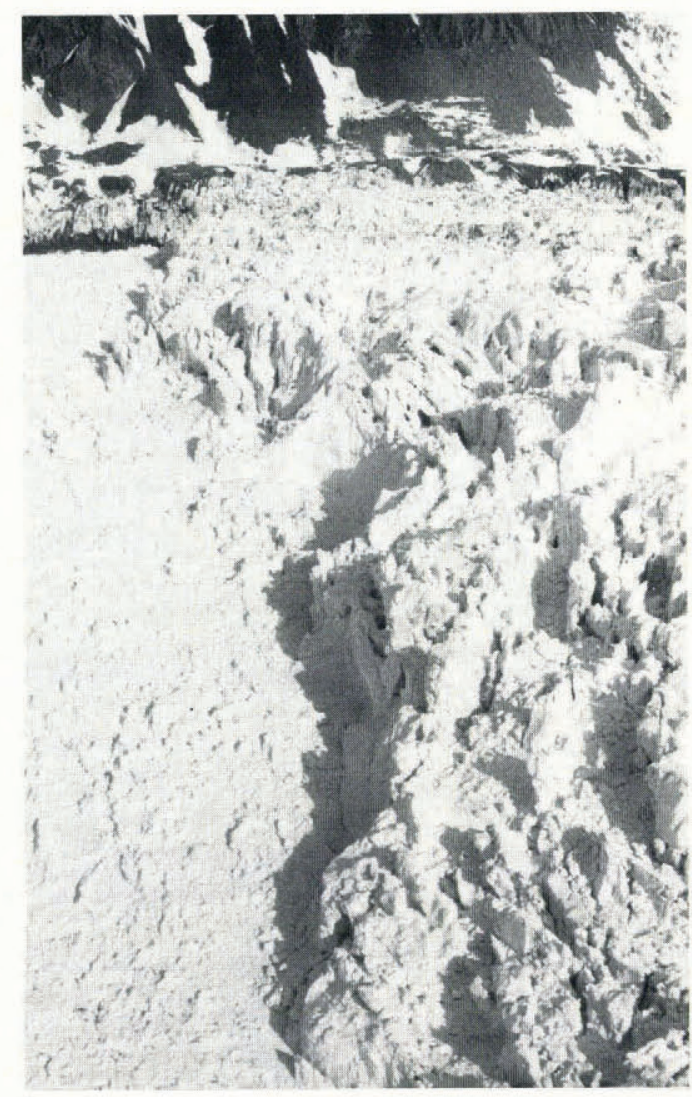

b

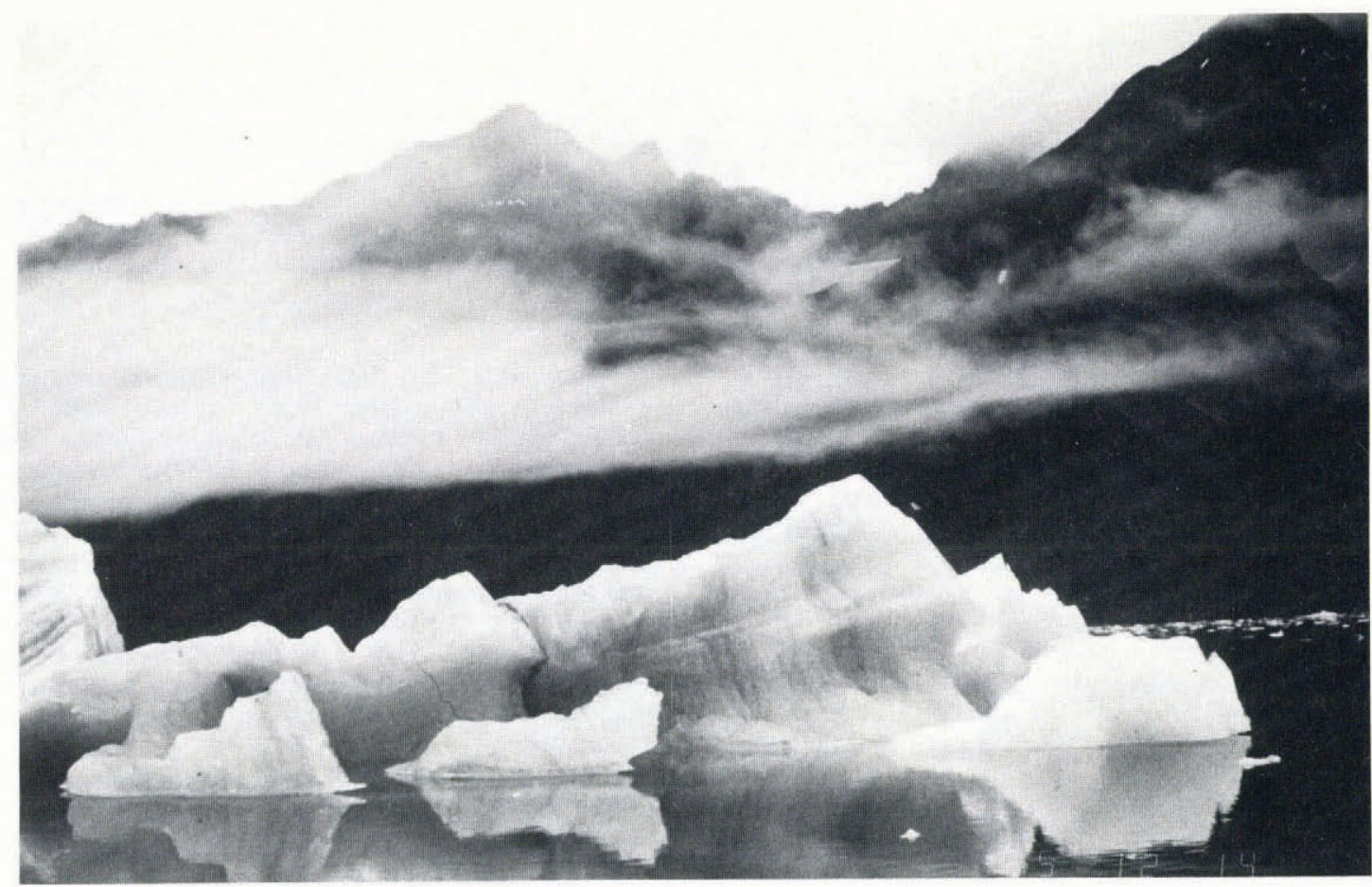

C

Fig. 2. Tinayrebukta and Tinayrebreen, north-west Spitsbergen, showing: (a) The crevassed glacier margin and scattered small icebergs in the fjord. Approximate distance across ice front $1.3 \mathrm{~km}$ (Norsk Polarinstitutt (NP) aerial photograph S70 4023, 22 August 1970); (b) The winter ice front, showing small icebergs within fast ice. Distance to glacier margin $800 \mathrm{~m}$; (c) Iceberg with irregular morphology (maximum height $6 \mathrm{~m}$ above water line). 
surges, but few have the long time series of observations necessary to confirm this.

\section{Tinayrebreen, north-west Spitsbergen}

This tide-water valley glacier has a steep longitudinal ice-surface profile and is heavily crevassed, indicating that it is relatively active (Fig. 2a). Water depth $400 \mathrm{~m}$ from the terminal ice cliffs is approximately $80 \mathrm{~m}$ (manuscript in preparation by J.A. Dowdeswell and others). The calving of small icebergs and their presence within the adjacent fjord has been observed directly and from aerial photographs. Most icebergs are less than $20-25 \mathrm{~m}$ in length, and all those observed are irregular in shape (Fig. 2c). This is a result of the crevassed nature of the tide-water terminus of Tinayrebreen. As icebergs calve from the terminus, a large number of bergy bits ( $<10 \mathrm{~m}$ across) and much brash ice ( $<2 \mathrm{~m}$ diameter) is also produced. Observations during airborne reconnaissance in May 1986 and 1987, when sea ice is still present in the fjord, indicate that some winter iceberg production also takes place (Fig. 2b), although the rate is probably considerably reduced over that in summer (Boulton, 1986).

\section{Paulabreen and Scheelebreen, Rindersbukta, Spitsbergen}

These two tide-water glaciers, 1.5 and $0.75 \mathrm{~km}$ wide, respectively, terminate in Rindersbukta at the head of Van Mijenfjorden. Water adjacent to the margin of Paulabreen is shallow, and several small islands appear above the surface. Airborne RES data for the glaciers indicate that they are between 60 and $80 \mathrm{~m}$ thick about $2 \mathrm{~km}$ from their termini (Dowdeswell and others, 1984). Both glaciers have low surface gradients and very few crevasses, indicating that their termini are relatively stagnant. Summer aerial photographs indicate that little calving is taking place (Fig. 3a), and only a few isolated ice blocks were observed close to the glacier fronts in the winter sea-ice cover (Fig. 3b). There is some evidence that Paulabreen may have
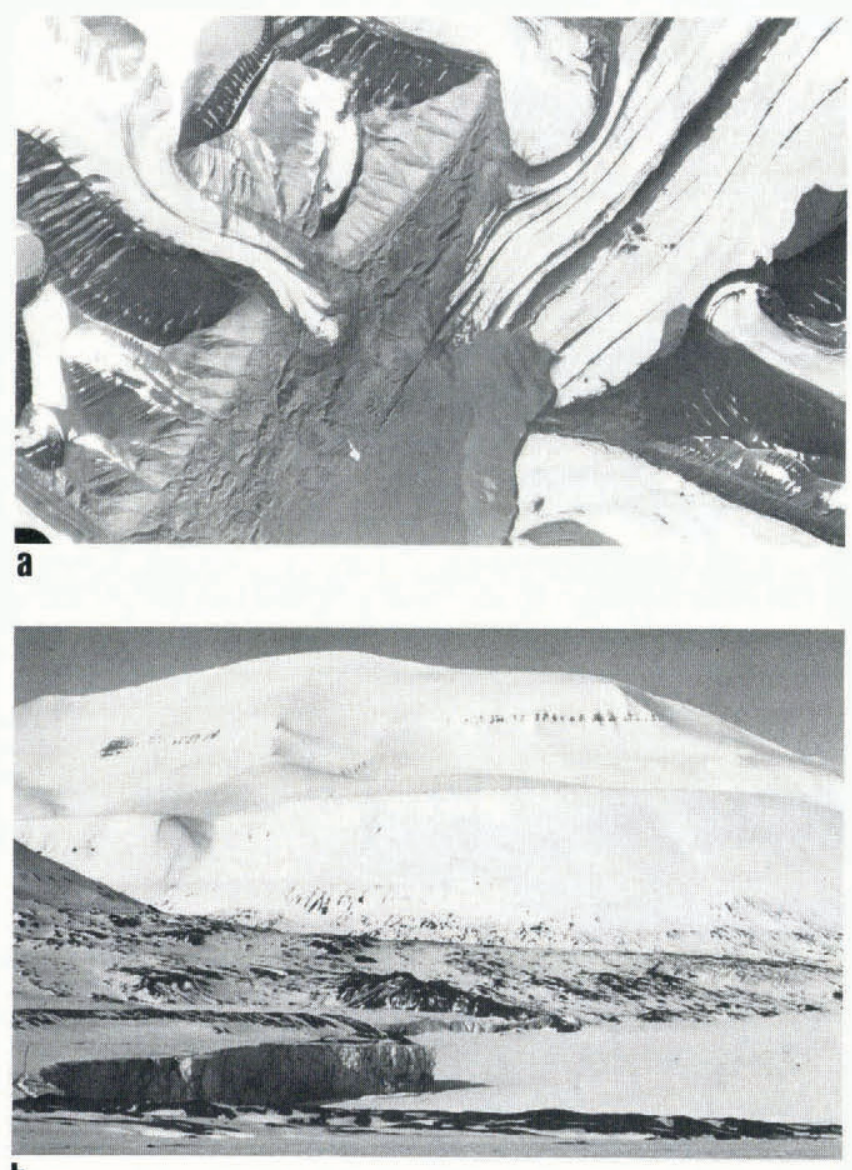

b

Fig. 3. The tide-water termini of Paulabreen and Scheelebreen in Rindersbukta, Van Mijenfjorden. (a) Aerial photograph from 23 August (NP S70 4616), showing few icebergs (the fjord is approximately $1.5 \mathrm{~km}$ wide close to the ice cliffs); (b) Photograph from early May, showing sea-ice cover and absence of icebergs. undergone a surge at the turn of the century (Rowan and others, 1982), and surge activity since 1985 on a tributary (Bakaninbreen) may affect the terminus of Paulabreen within the next few years. There is no record of past surges for Scheelebreen.

\section{ICEBERGS CALVED FROM ICE CAPS AND LARGE OUTLET GLACIERS}

Ice caps and large outlet glaciers become the dominant mode of glacierization in eastern Svalbard. Observations are from the ice caps of eastern Nordaustlandet.

Eastern Austfonna, Nordaustlandet

The eastern side of Austfonna is composed of over $150 \mathrm{~km}$ of tide-water ice cliffs, interrupted at only two points by restricted rock outcrops (Fig. 1). Direct observations on flights over these areas in 1983, 1986, and 1987, together with the analysis of aerial photographic evidence, show that, along with smaller icebergs of irregular shape, tabular icebergs are also produced from these ice cliffs. We have observed tabular icebergs with long axes of up to $600 \mathrm{~m}$ immediately offshore of the eastern ice cliffs of Austfonna (Fig. 4a). Tabular icebergs calved from this area are usually rectangular in plan, because of the presence of large crevasses trending parallel to the terminal ice cliffs (Fig, 4b). The calving of tabular icebergs also produces

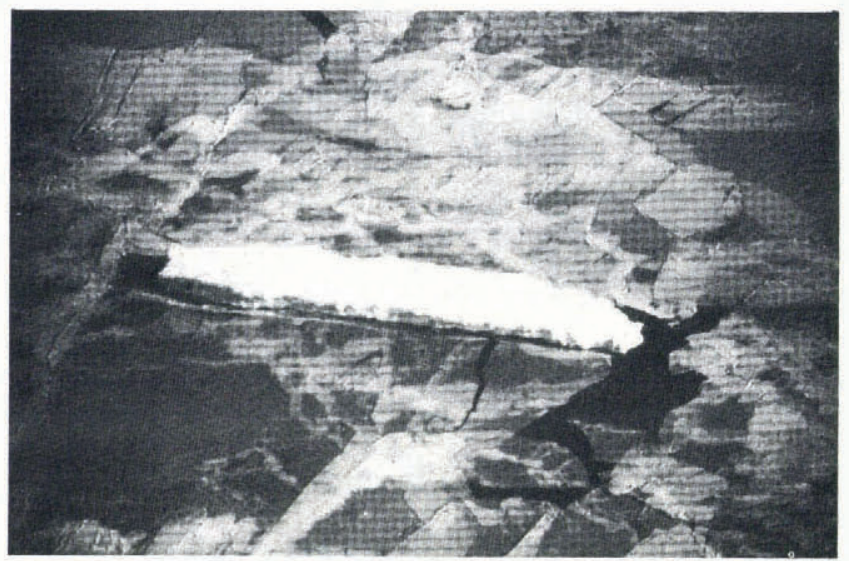

a

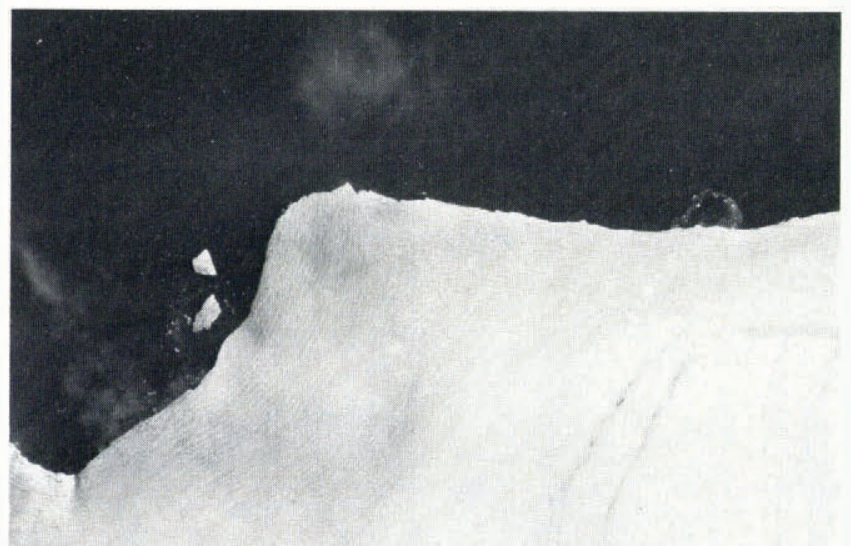

b

Fig. 4. Icebergs and ice cliffs on the east coast of Austfonna, Nordaustlandet, showing (a) a tabular iceberg about $600 \mathrm{~m}$ in length within newly formed sea ice (photograph by Dr D.J. Drewry); (b) Ice cliffs, supraglacial drainage channels, and widely spaced marginal crevasses on Austfonna. The two tabular icebergs are about $200 \mathrm{~m}$ in diameter. Width across photograph approximately $5 \mathrm{~km}$ (NP S70 5213, 29 August 1970). 
bergy bits ( $<10 \mathrm{~m}$ across) in abundance, and icebergs of irregular shape also result from the collapse of smaller lengths of ice cliff (Fig. 4b).

Airborne RES can be used to determine the likely maximum thickness of these tabular icebergs. Evidence from a detailed network of radar-sounding flight lines over the eastern, tide-water margins of Austfonna (Dowdeswell and others, 1986) provides data on the thickness of the grounded ice-cap margin (Fig. 5). The marine margins of eastern Austfonna range between $75 \mathrm{~m}$ and over $125 \mathrm{~m}$ below sea-level, with the greatest ice thicknesses in the Hartogbukta area (Fig. 1).

A similar calving regime, including the production of tabular and smaller, less regularly shaped icebergs, has been observed during airborne reconnaissance and from aerial photographs around the ice cliffs of Kvitøya and from the $25 \mathrm{~km}$ long tide-water margins of Leighbreen, an outlet glacier in north-east Nordaustlandet (Fig. 1).

\section{ICEBERGS CALVED FROM SURGE-TYPE GLACIERS}

Surge-type glaciers provide the clearest demonstration of the way in which ice-mass dynamics affect the nature of iceberg calving. Surges are characterized by velocity increases of several orders of magnitude, usually accompanied by rapid glacier advance, and the transfer of mass from an upper, accumulation area to a lower receiving zone (Meier and Post, 1969). This behaviour is a result of enhanced lubrication and high water pressures at the glacier bed, inducing rapid sliding (Kamb and others, 1985). It persists for only one to a few years and is followed by a much longer quiescent period, during which the ice-mass terminus stagnates and retreats, while snow accumulation provides mass input and renewed build-up in the upper basin.

A large number of ice masses in Svalbard have been observed to undergo periodic surges punctuating longer quiescent periods, and many of these glaciers end in tide water (Liestøl, 1969; Schytt, 1969). Examination of aerial photographs allowed comparison of a number of Svalbard tide-water ice masses in both the active and quiescent phases of their surge cycles. Two examples follow, but discussion is based on this more extensive observational data set.

\section{Brảsvellbreen, Austfonna, Nordaustlandet}

Bråsvellbreen now drains a basin of about $1100 \mathrm{~km}^{2}$ on the south side of Austfonna (Dowdeswell and Drewry, 1985). It illustrates the nature of icebergs calved both during surge activity and in the longer quiescent period.

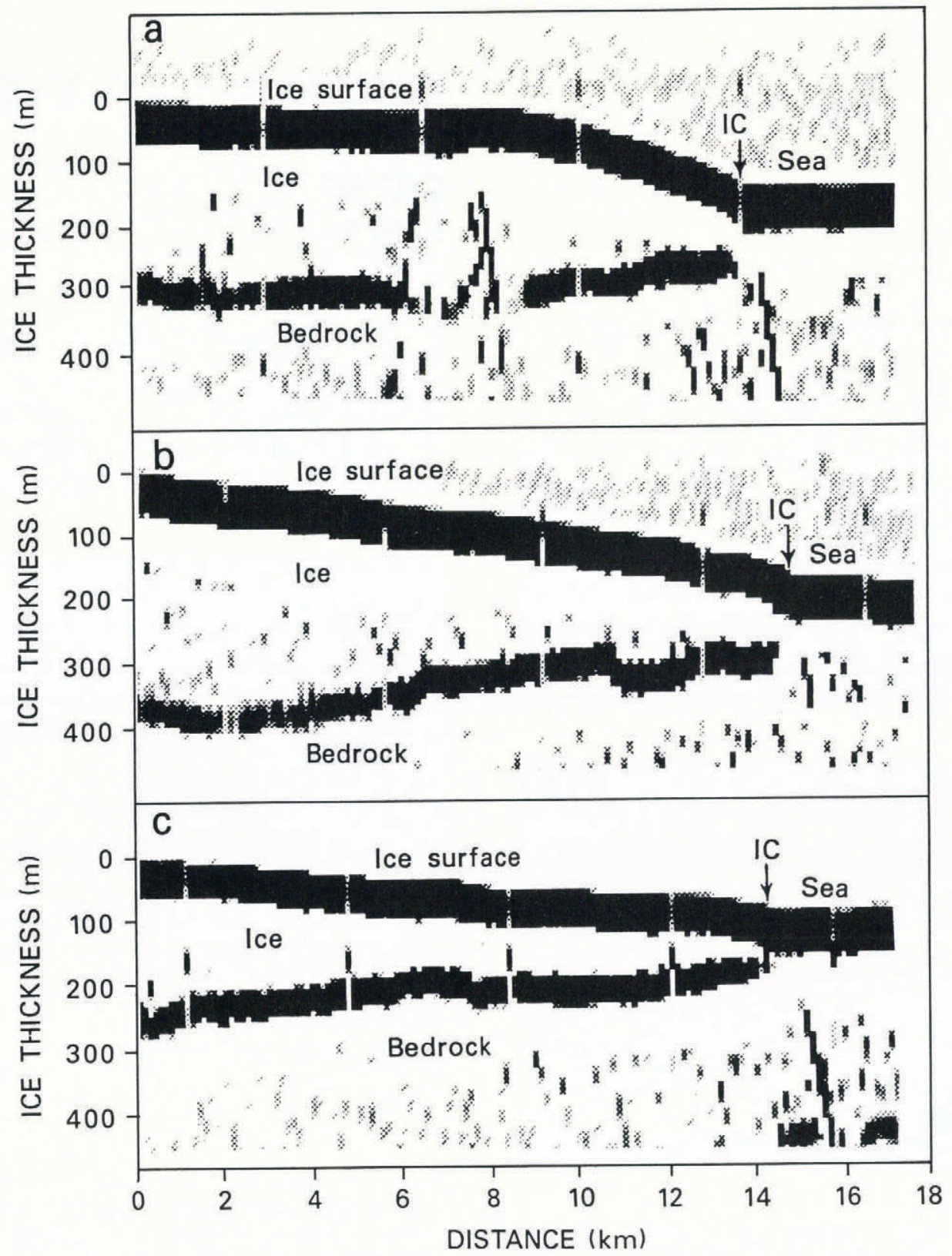

Fig. 5. Airborne radio echo-sounding profiles of ice thickness on Austfonna, Nordaustlandet. For locations see Figure 1. Flight lines run orthogonal to the coast, and points marked IC represent crossing of the coastal ice cliffs. Ice at the tide-water margin is approximately $120-125 \mathrm{~m}$ thick in (a) and (b), and $105 \mathrm{~m}$ thick in (c). 
Between 1936 and 1938 the basin underwent a surge, its seaward margin advancing by up to $20 \mathrm{~km}$ along a $30 \mathrm{~km}$ front (Schytt, 1969). Oblique aerial photographs from 1938 indicate that at least an order-of-magnitude more icebergs was produced during the surge than in the quiescent phase (Fig. 6). More recent aerial photographs show that iceberg calving is now limited to occasional collapse events (Fig. 6b). The surging ice-mass surface was also chaotically

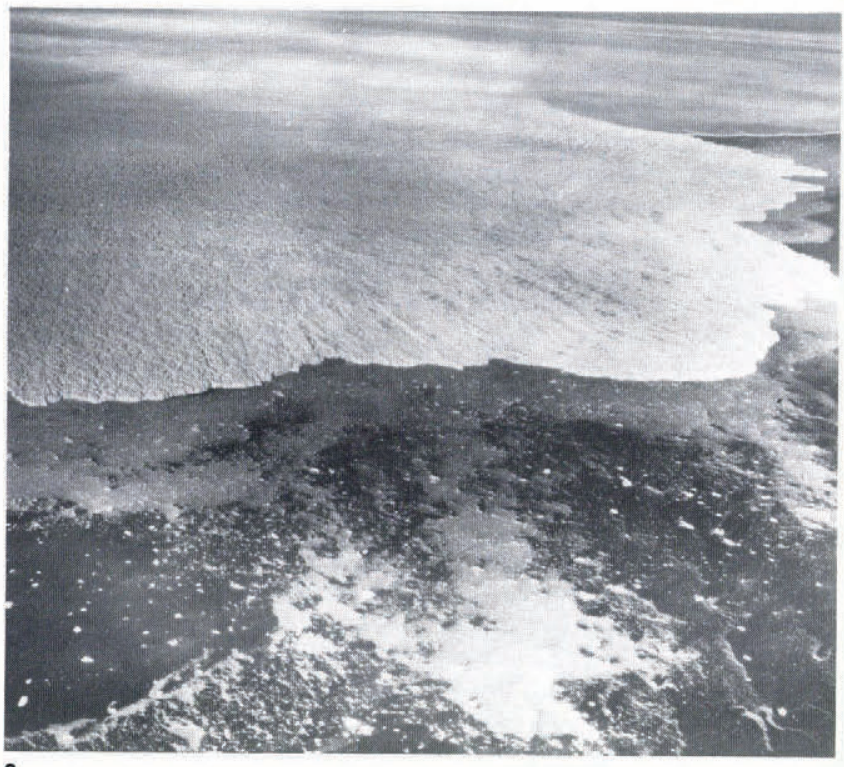

a

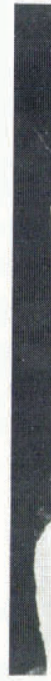

b

Fig. 6. Bräsvellbreen, Nordaustlandet. (a) Oblique aerial photograph showing the heavily crevassed surface and large numbers of calved icebergs during the 1938 surge (NP S38 1958); (b) The quiescent-phase surface in 1970. showing perennial melt-water streams and general lack of crevassing (NP S70 5212, 29 August 1970).

crevassed. Calved icebergs were generally limited in size by crevasse spacing, which was usually less than $30-50 \mathrm{~m}$ apart. Solheim and Pfirman (1985) have also used side-scan sonar records to show that the frequency of gouges on the sea floor off Bråsvellbreen increases markedly beyond the moraine marking the limits of the surge. This is partly due to the short time the sea floor inside the moraine has been exposed by post-surge retreat, but is also associated with the large number of icebergs affecting the sea floor during the surge. In 1983, ice thickness from RES was also less than $100 \mathrm{~m}$ close to the seaward margin, and water depths of between 30 and $85 \mathrm{~m}$ have been measured immediately beyond the terminal ice cliffs (Solheim and Pfirman, 1985). Thus, the rate of iceberg calving is today limited by stagnation of the ice mass in shallow water, and the dimensions of calved icebergs are limited by the reduced ice thickness in response to low surface gradients and a lack of mass replacement from up-glacier.

\section{Etonbreen, Austfonna, Nordaustlandet}

Aerial photographs from the summer of 1938 show that Etonbreen, a $7 \mathrm{~km}$ wide outlet glacier on Nordaustlandet, was surging and highly crevassed (Fig. 7a). Large volumes of ice were being calved into the adjacent fjord in the form of icebergs, bergy bits, and brash ice. Most icebergs were, with a few exceptions, less than $50 \mathrm{~m}$ in diameter, and were irregular in form.

Comparison with 1969 and 1970 aerial photographs shows that the ice front had retreated by up to $3 \mathrm{~km}$ since 1938. Crevassing, although still present, was more restricted in extent, and perennial streams were well developed on the southern part of the outlet glacier (Fig. 7b). This indicates

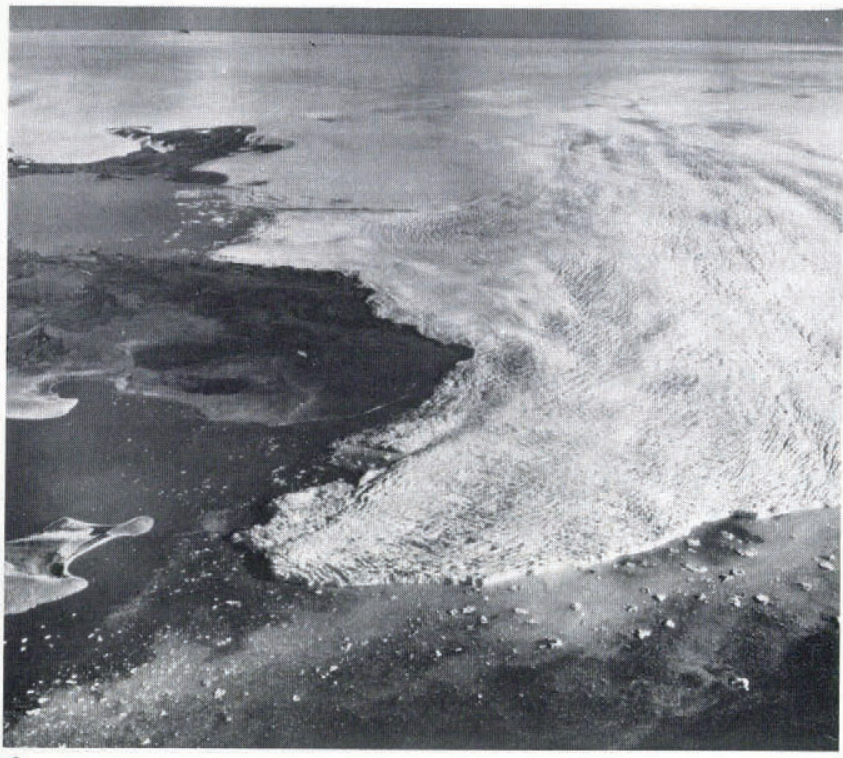

a

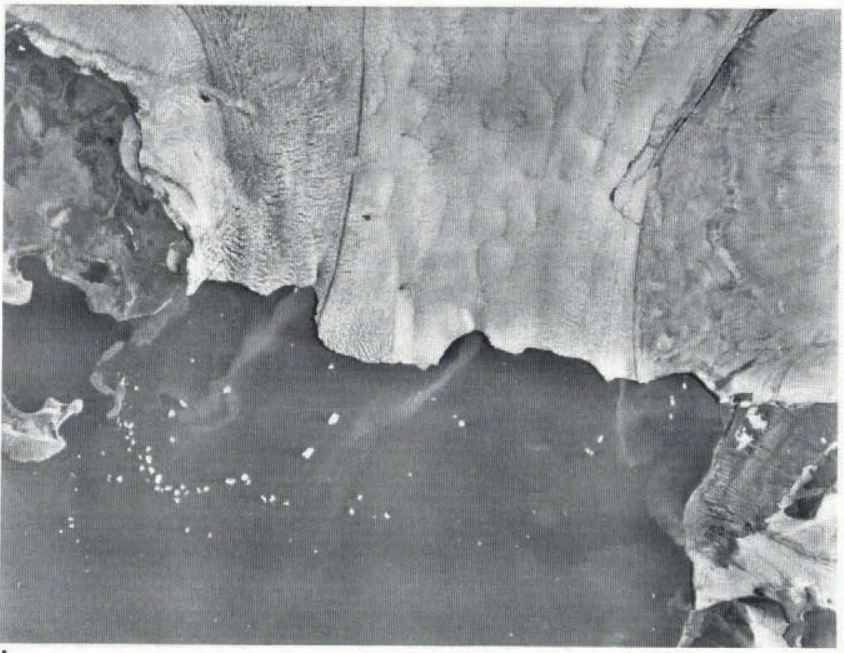

Fig. 7. Etonbreen, Nordaustlandet. (a) Oblique aerial photograph of the crevassed surface and many calved icebergs during the surge in the summer of 1938 (NP S38 2057); (b) The glacier is in the quiescent period between surges. Note that some crevassing is present, indicating limited activity. Several icebergs between 50 and $100 \mathrm{~m}$ across are present in the fjord. Width of photograph about $10.5 \mathrm{~km}$ (NP S70 3632, 29 August 1970).

that Etonbreen is not completely stagnant, but was nonetheless significantly less active than during its surge in the late 1930s. Iceberg production in 1969 and 1970 contrasted with the surge phase, and a number of icebergs between 100 and $200 \mathrm{~m}$ in diameter were observed (Fig. 7b). Most were irregular in shape, but several more tabular examples were also noted. The total number of icebergs present was, however, significantly smaller than 
during the surge. The very limited numbers of bergy bits and amount of brash ice present in the later period also suggests that the rate of calving was reduced significantly.

\section{DISCUSSION: THE NATURE OF SVALBARD ICEBERGS}

The relative number of icebergs produced by each type of calving ice mass, and the dominant shape of these icebergs, are summarized in Table II. The crevassed, more

TABLE II. RELATIVE NUMBERS OF ICEBERGS PRODUCED AND DOMINANT ICEBERG CHARACTER FROM DIFFERENT TYPES OF SVALBARD TIDE-WATER ICE MASS

Type of ice mass

Tide-water valley glacier

(crevassed margin)

Tide-water valley glacier

(little crevassing)

Ice cap/large outlet

Surge-type glacier (active)

Surge-type glacier (quiescent)

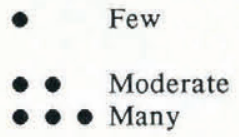

Small irregular icebergs,
bergy bits
Larger irregular icebergs
- - Tabular icebergs

active tide-water glaciers produce relatively large numbers of icebergs. Few are greater than $40 \mathrm{~m}$ across. Calving also results in the production of many small icebergs, bergy bits, and brash ice. Crevasse spacing and vertical ice thickness place effective limits on iceberg dimensions. Crevasse spacing measured from aerial photographs is normally of the order of $20-50 \mathrm{~m}$. These icebergs of ten exhibit an irregular abovewater morphology (Fig. 2c), and many show former water lines indicating that they have overturned. This is expected, because their small and irregular dimensions mean that they are relatively unstable in the presence of wind, wave or current activity (Kristensen and others, 1982).

RES studies of many tide-water valley glaciers show that ice thickness close to the terminus is seldom greater than $100 \mathrm{~m}$ (Dowdeswell and others, 1984). This, in turn, implies that water depths immediately offshore are often less than $70-80 \mathrm{~m}$. Brown and others (1982) have shown for a number of Alaskan tide-water glaciers that iceberg-calving rates increase rapidly with increasing water depth. It is not surprising, therefore, that few Svalbard tide-water glaciers are grounded in deeper water. This is because, in order to sustain such a deep-water glacier terminus, and its associated high calving rate, very high mass inputs and mass transfers down the parent glacier would be required.

The rate of production of icebergs from more stagnant, often less crevassed tide-water glaciers is much less than from active glaciers (Table II). Airborne RES investigations of ice thickness and surface altimetry show that the margins of these more stagnant tide-water glaciers typically have low surface gradients and a thickness of only $50-75 \mathrm{~m}$ below the water line (Dowdeswell and others, 1984). However, the horizontal cross-section of calved icebergs may be somewhat larger than icebergs from more active tide-water glaciers due to the relative lack of crevasses.

Most smaller icebergs, bergy bits, and brash ice calved into Svalbard fjords will disintegrate and melt in this environment without reaching open sea. For example, in Tinayrebukta, north-west Spitsbergen, the drift of several icebergs of distinctive morphology, with maximum length $30 \mathrm{~m}$ and maximum freeboard $5 \mathrm{~m}$, was observed. Over a $5 \mathrm{~d}$ period with light, variable winds these icebergs circulated within the $6 \mathrm{~km}$ long fjord rather than simply moving towards the open sea, presumably in response to the tidally driven currents.

Sea-bed topography can also prevent larger icebergs moving rapidly away from their tide-water glacier source, and much melting may therefore take place in relatively glacier-proximal locations. Relatively shallow sills forming semi-enclosed basins are common features close to the margins of Svalbard fjord tide-water glaciers (e.g. Elverhøi and others, 1983). Some sills are structural bedrock features. A large number of shallow sills also result from the deposition of moraine ridges associated with glacier advances in response to Little Ice Age climatic change and surge activity. They are present on acoustic records and charts of many Svalbard fjords (Elverhøi and others, 1983).

The production of tabular icebergs from the ice caps in eastern Svalbard contrasts with the smaller icebergs of more irregular shape calved from tide-water glaciers (Table II). By virtue of their large size, these icebergs can travel significantly longer distances from their source before melting is complete. Tabular icebergs are also relatively stable, and are less likely to undergo successive overturning events than irregular-shaped icebergs, at least until relatively late in their disintegration history. This applies in particular to tabular icebergs which are equidimensional in plan, rather than those with a high long-to-short axis ratio.

Little is known about the tracks followed by the larger tabular icebergs calved from eastern Svalbard, although Vinje (1985) summarized the drift of automatic buoys and ice floes around the Svalbard archipelago and in the Barents Sea, based on data for the period 1970-80. The presence of soft glacimarine muds with dropstones and recent iceberg gouges on the sea bed in the north-west Barents Sea shows, along with direct observations, that some larger icebergs are escaping into open water (Elverhøi and Solheim, 1983; Solheim and others, 1988). The recent gouges or plough marks are found down to water depths of $90-100 \mathrm{~m}$, and are distinguished from relict features by their well-defined morphology on side-scan sonar records. While the origin of icebergs producing these gouges cannot be positively identified, it is likely that at least some are derived from the large sections of continuous ice cliffs on the east coasts of Nordaustlandet and Edgeøya, where relatively large tabular icebergs have been observed (Figs 4a and 10a).

The active phase of the surge cycle has several consequences relevant to iceberg production and dimensions. First, the rate of iceberg production is enhanced (Figs 6a and 7a; Table II) through increased ice flux to the tide-water ice margins and the advance of the crevassed terminus into water that may also be deepening offshore. Secondly, the dimensions of these calved icebergs are reduced because of the close spacing of crevasses and chaotic crevasse alignment both normal and parallel to flow (Figs 6a and 7a; Table II). During the longer, quiescent period between surges, calving is usually limited because the parent glacier is largely stagnant.

\section{ICEBERG INTERACTIONS WITH SEA ICE}

The sea-ice conditions around Svalbard vary with season, with the degree of exposure to storm waves, and in response to the oceanographic circulation about the archipelago. A continuous cover of fast ice forms in the major fjord systems and in other sheltered coastal areas of restricted geometry by about late November, and is usually retained until late May or June (Fig. 8) (Wadhams, 1981). Precise dates vary from year to year, and with degree of exposure to wind and wave action. Arctic pack ice is usually present around north-east Svalbard throughout the year, although the lowest floe densities occur in August and September (Lunde, 1965; Vinje, 1985). Between November and April, pack ice may be found around the whole archipelago, with minimum densities on the west coast of Spitsbergen. The asymmetric distribution of polar pack ice is due to the oceanic circulation, with polar waters bringing pack ice south around Nordaustlandet, Kong Karls Land and Kvitøya, and the warmer West Spitsbergen Current flowing northwards along the western side of Svalbard (Wadhams, 1981; Vinje, 1985).

Two examples of iceberg-sea-ice interactions are 


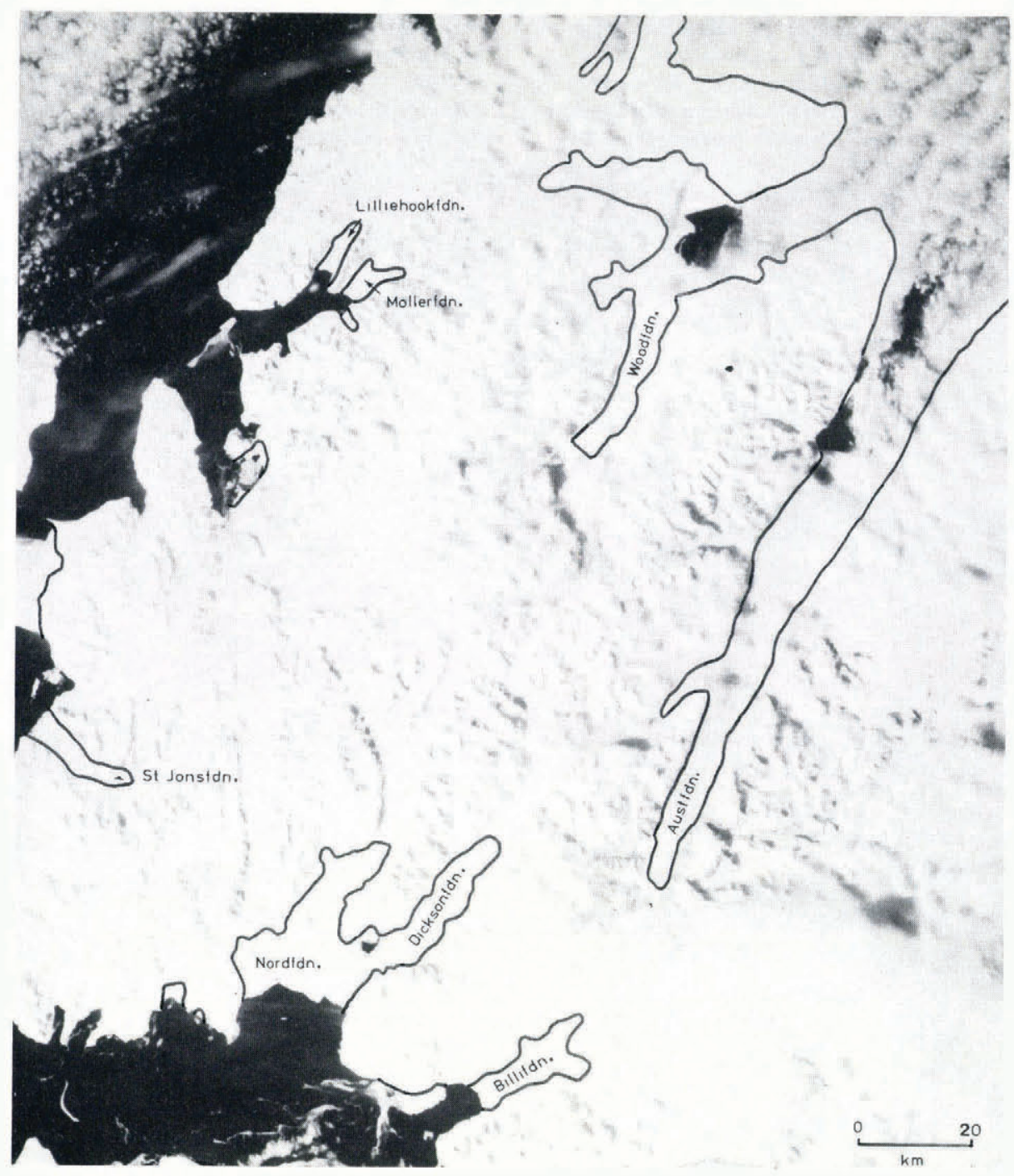

Fig. 8. Landsat Multispectral Scanner (MSS) scene of north-west Spitsbergen imaged on 5 May 1984. The land is still snow-covered and fast ice occupies many of the sheltered fjords. The coast is outlined where fast ice persists.

discussed; one from a relatively sheltered fjord environment in north-west Spitsbergen, and the second from the contrasting, more exposed Barents Sea coast of Edgeøya (Fig. 1). The examples are representative of a much larger area of the archipelago, observed during airborne geophysical and reconnaissance flights.

\section{Lilliehöökbreen, north-west Spitsbergen}

This $5 \mathrm{~km}$ wide tide-water glacier calves icebergs into the head of a $30 \mathrm{~km}$ long fjord. Sea ice forms in early winter and is usually retained as a continuous cover of fast ice until June in the inner fjord (Fig. 8). The ice-covered inner fjord and tide-water margins of Lilliehöökbreen were observed in some detail in May 1986 and 1987. In both years, icebergs and bergy bits had calved from the terminal ice cliffs during winter, but remained trapped in the fast-ice cover within $0.5 \mathrm{~km}$ of the ice front (Fig. 9a). The largest icebergs were over $100 \mathrm{~m}$ in diameter, with a freeboard of about $10 \mathrm{~m}$. However, airborne inspection of the whole fast-ice cover showed that no icebergs were breaking the continuous, flat fast ice at a greater distance from the tide-water glacier. Similar clusters of icebergs and bergy bits close to tide-water glacier termini, but with little evidence of significant iceberg migration through the winter fast ice, were also observed in, for example, Möllerf jorden, Kongsfjorden, Nordf jorden, and Van Keulenf jorden in Spitsbergen (Figs 1 and 9).

\section{Stonebreen, Edgeøya}

The twin lobes of Stonebreen protrude beyond the general line of the east coast of Edgeøya by up to $20 \mathrm{~km}$ (Fig. 1). They are therefore in a position of considerable exposure to stress from waves and wind off the Barents
Sea. The formation and retention of continuous winter fast ice is therefore much reduced and less predictable in extent than on more sheltered coasts. However, pack ice composed of ice floes is usually present in this part of the Barents Sea for much of the year (Vinje, 1985). These ice floes are mobile, and drift in response to oceanographic and wind fields. Icebergs and bergy bits were observed in several environmental settings off Stonebreen during May 1987 (Fig. 10). First, icebergs up to $200 \mathrm{~m}$ across were noted in areas of relatively open water during airborne observations extending up to $15 \mathrm{~km}$ from the coastal ice cliffs (Fig. 10a). Secondly, icebergs and bergy bits were observed within mobile pack ice. Thirdly, where limited areas of fast ice were present, icebergs and associated bergy bits were found trapped close to their ice-cliff source (Fig. 10b). Thus, calving occurs during the winter along this $65 \mathrm{~km}$ length of tide-water ice cliffs, but the presence or absence of fast ice controlled whether or not those icebergs escaped immediately into open ocean. Observations of the similarly exposed east coast of Nordaustlandet in May 1983, 1986, and 1987 revealed a similar pattern of iceberg-sea-ice interaction.

\section{Interpretation}

The pattern of sea-ice distribution in space and time has several implications for iceberg movement. In the major fjords of Spitsbergen and northern Nordaustlandet, the presence of fast ice has two main effects. First, it is one of several processes restricting winter iceberg calving. Secondly, it curtails the movement of any icebergs that are calved during the winter months.

The presence of winter fast ice protects the ice cliffs at the margins of tide-water ice masses. Undercutting and impact stress from wave action are effectively suppressed. 
The winter calving rate of such glaciers is therefore likely to be significantly reduced over summer iceberg production, particularly when the effects of a reduction of ice-surface velocity during winter (e.g. Voigt, 1965), and the likelihood of melt water freezing in crevasses during winter are also considered (Boulton, 1986). Indeed, winter observations at the tide-water margins of Aavatsmarkbreen, Spitsbergen, indicated a lack of calved ice blocks, but the presence of buckled and overthrust sea ice suggested a winter re-advance of the glacier terminus (Boulton, 1986).
Icebergs calved in winter have been observed, nonetheless, punctuating the relatively smooth fast-ice surface immediately beyond the tide-water termini of a number of Spitsbergen ice masses (Fig. 9). These icebergs are held in this location until break-up in spring. Very few are seen, either trapped or moving, within fast ice at any distance from glacier margins, indicating that winter iceberg movement is severely restricted where fast ice is present. These icebergs will therefore be released as a pulse into fjords and sheltered areas of the archipelago on the decay and break-up of the fast ice in late May or June.
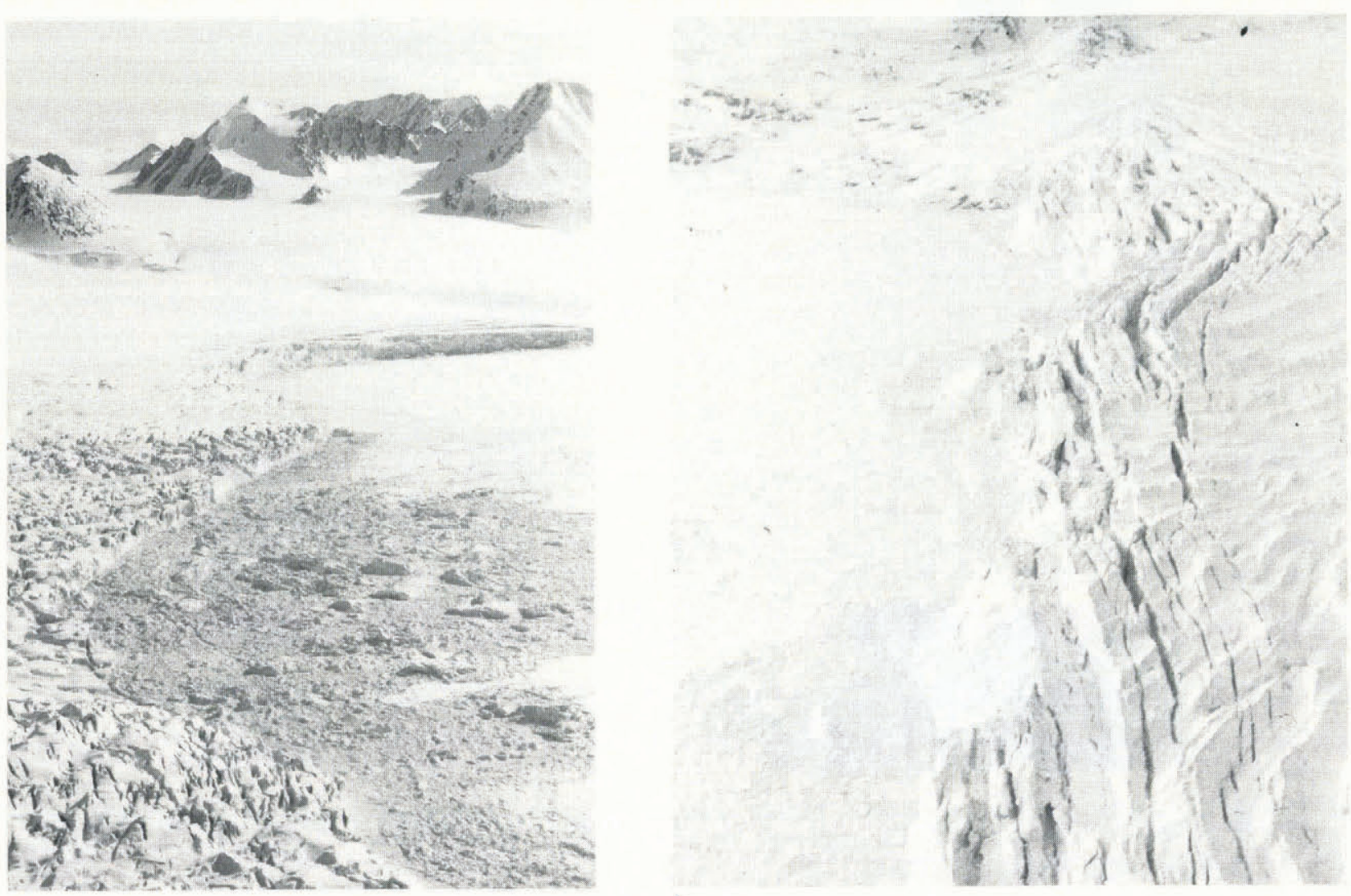

a

\section{b}
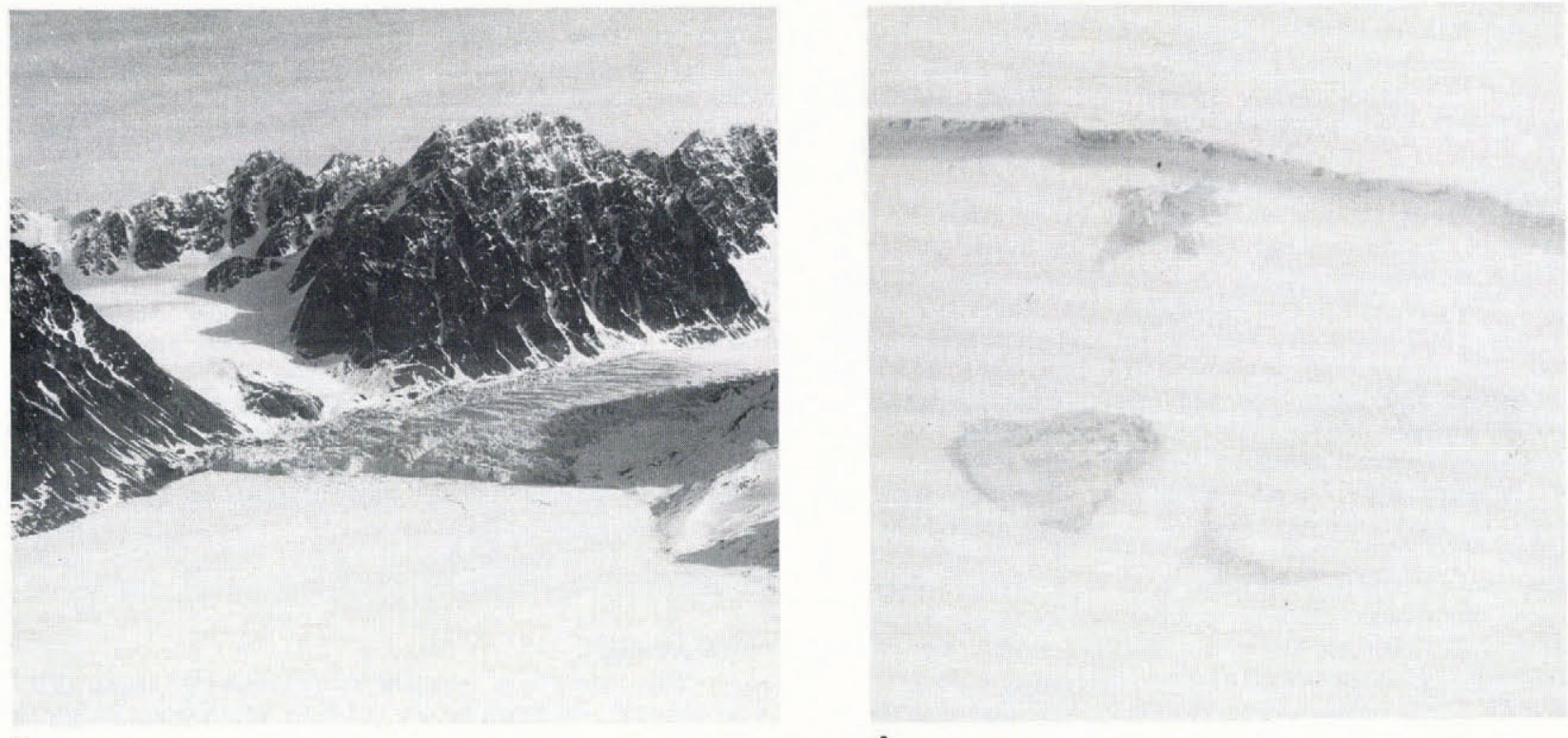

Fig. 9. Icebergs and winter fast ice. (a) Icebergs immediately off the ice cliffs of Lilliehöökreen (ice front extends about $2.5 \mathrm{~km}) ;($ b) Small icebergs calved from the winter front of Nordenskiöldbreen, Billefjorden $(0.7 \mathrm{~km}$ to glacier margin); (c) Unbroken fast ice with no icebergs except close to the tide-water margin of Mayerbreen. Möllerfjorden (fjord approximately $1.5 \mathrm{~km}$ wide); (d) Recently calved tabular icebergs in fast ice close to the ice cliffs of Negribreen, Storfjorden (largest iceberg approximately $150 \mathrm{~m}$ in diameter). 


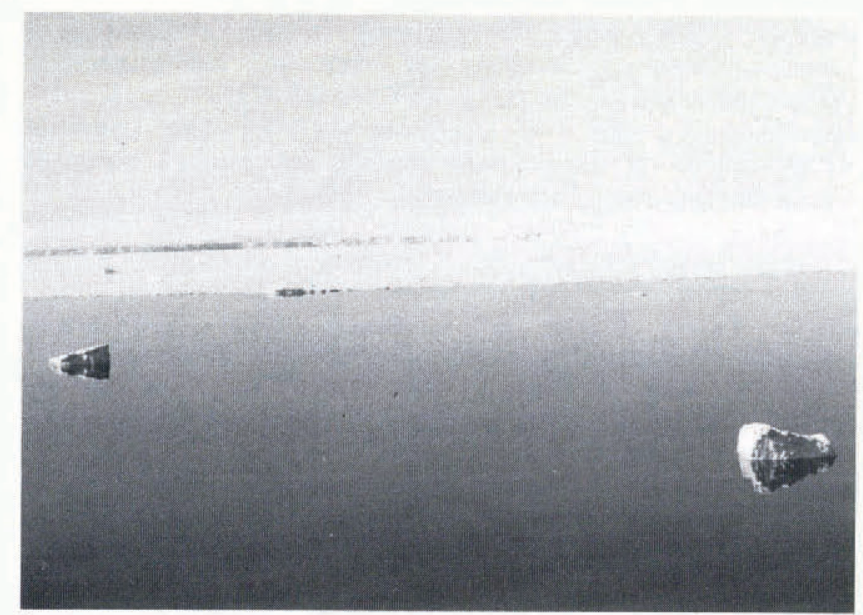

a

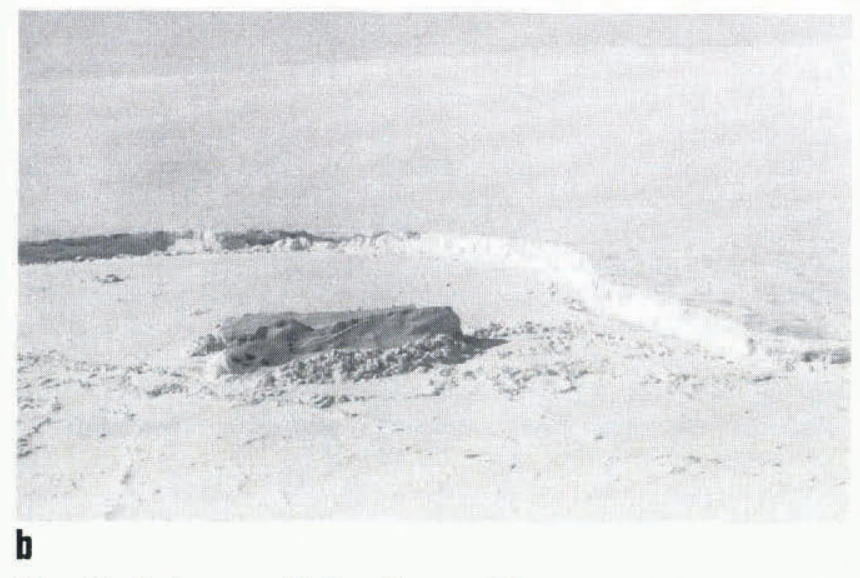

Fig. 10. Icebergs off Stonebreen, Edgeøya, in May 1987. (a) Icebergs in open water beyond fast ice fringing Stonebreen (icebergs approximately $100 \mathrm{~m}$ in length); (b) Large and small icebergs in fast ice close to the tide-water margins of Stonebreen (ice cliffs $25 \mathrm{~m}$ high).

Once summer calving or release from winter fast ice has occurred, icebergs are susceptible to overturn and fragmentation when exposed to wave and wind forcing (e.g. Kristensen and others, 1982; Wadhams and others, 1983). The presence of ice floes acts to damp wave energy (e.g. Squire and Moore, 1980), and any iceberg moving within a pack-ice field will experience considerable protection from wave perturbations. The degree of protection increases with distance into the pack ice from the sea-ice margin and with increasing floe density (Squire and Moore, 1980). Thus, icebergs in pack ice off north-east Svalbard will be less likely to experience overturn stimulated by wave forcing than icebergs of comparable dimensions in open ocean off the west coast. Protection from storm waves and ocean swell is also provided within the major fjord systems of the archipelago, and overturn is less likely here than in the open ocean.

\section{SOME IMPLICATIONS FOR GLACIMARINE SEDI- MENTATION}

The observations reported here on the relative rates of iceberg production, and the dimensions of calved icebergs, have several implications for the sedimentation of ice-rafted debris in the marine environment around Svalbard.

The content and distribution of debris within a sample of north-west Spitsbergen icebergs has been described by Dowdeswell and Dowdeswell (1989). Calculations concerning the melt rate of these icebergs suggested that most debris would be released within a few days to 2 months of calving. The large, tabular shape of some icebergs calved from the ice caps of eastern Svalbard has several important consequences for the nature of subsequent debris rafting and release. Large tabular icebergs can contribute to more distal sedimentation than their smaller, less regular counterparts because they will take longer to melt. Englacial debris-rich bands within tabular icebergs (Anderson and others, 1980; Dowdeswell and Dowdeswell, 1989) will contribute to sedimentation even after any basal debris-rich ice layer has been melted out. Any sediment melting out on the surface of a tabular iceberg is also likely to survive there for considerably longer than on smaller, less stable icebergs.

Surges of ice masses ending in tide water also affect the rate and pattern of glacimarine sedimentation from the icebergs calved from them. Iceberg sedimentation, particularly in proximal locations, will increase rapidly during surges because (i) a wery large number of icebergs is released at this time, the total iceberg flux being significantly greater than under a quiescent-period dynamic regime; (ii) the decrease in average iceberg size, relative to non-surge conditions, results in more rapid melting, and therefore in debris release relatively close to the glacier terminus; (iii) icebergs may contain thicker debris-rich zones than those derived from non-surging glaciers due to enhanced opportunities for debris incorporation during surges (Clapperton, 1975). However, sediment deposition from glacier-derived melt water which is rich in suspended material will also increase during or at termination of a surge (Kamb and others, 1985). Thus, the mass of iceberg-rafted material deposited will grow during surges, but it may not necessarily make up a larger relative proportion of total glacimarine sedimentation than during quiescence.

Finally, modelling studies have indicated that if ice masses terminating in water begin to float and form ice shelves, then basal melting may remove significant thicknesses of basal ice and included debris before iceberg calving occurs (Drewry and Cooper, 1981). Thus, icebergs derived from floating ice shelves may in some cases raft little debris into the marine environment. Evidence from airborne radio echo-sounding studies of a large number of Svalbard ice masses ending in tide water shows that no significant areas of ungrounded glacier ice are present around the archipelago (Dowdeswell and others, 1984, 1986). Svalbard icebergs should not, therefore, be depleted in basal sediment prior to calving.

\section{CONCLUSIONS}

Over $1000 \mathrm{~km}$ of the coast of Svalbard is composed of ice masses ending in tide water. Icebergs are calved throughout this length, but the nature of the icebergs produced varies considerably. The morphology and dynamics of the parent ice mass are fundamental controls on the size, shape, and relative rate of iceberg production. The effects of glacier activity and scale of glacierization on the nature of calved icebergs are indicated in Table II and are summarized below:

(i) Active, crevassed tide-water valley glaciers in Svalbard fjords produce relatively large numbers of irregularly spaced small icebergs (of ten $<40 \mathrm{~m}$ in length).

(ii) Less active tide-water glaciers yield small numbers of icebergs, but they may be larger than those from more heavily crevassed tide-water glaciers because the ice-mass surface is less broken.

(iii) Larger ice caps in eastern Svalbard have been observed to produce tabular icebergs up to $600 \mathrm{~m}$ long, as well as smaller icebergs and brash ice. However, relatively few large icebergs are calved.

(iv) Surge-type glaciers in the short, active phase of a surge cycle produce very many small icebergs ( $<50 \mathrm{~m}$ in length) of irregular shape.

(v) In the longer, quiescent period between surges, few icebergs are produced from the thin, stagnant termini of surge-type tide-water glaciers and ice caps.

The pattern of sea-ice distribution around Svalbard also influences the nature of iceberg calving. Winter fast ice protects tide-water glacier termini, and the rate of iceberg calving is suppressed. Where winter calving does take place, icebergs are trapped close to the ice front. They are released as a pulse during spring fast-ice break-up. Calving rate is curtailed most in protected Svalbard fjords where fast ice is present each winter. Iceberg-overturn events are 
also reduced in pack-ice fields, where wave energy is damped, but are more frequent when icebergs of irregular shape are calved.

Sedimentation from icebergs into the marine environment may increase during glacier surges due to the high rate of production of small icebergs, and a possible increase in their sediment content (Clapperton, 1975). Large, tabular icebergs will transport included debris the farthest distance from parent tide-water ice masses. There is no evidence of significant areas of floating glacier ice around Svalbard, precluding the loss of basal debris from parent ice masses prior to iceberg calving.

\section{ACKNOWLEDGEMENTS}

Observations were made during a series of field seasons organized through the Scott Polar Research Institute, University of Cambridge. Funding from NATO Collaborative Research Grant 0747/87 allowed extensive discussion with A. Solheim. A. Elverhøi and T. Vinje also provided helpful comments. Dr S. Helle and T. Eiken kindly allowed full access to the Svalbard aerial photograph collection at the Norsk Polarinstitutt, and granted permission for several photographs to be reproduced here.

\section{REFERENCES}

Anderson, J.B., E.W. Domack, and D.D. Kurtz. 1980. Observations of sediment-laden icebergs in Antarctic waters: implications to glacial erosion and transport. $J$. Glaciol., 25(93), 387-396.

Boulton, G.S. 1986. Push-moraines and glacier-contact fans in marine and terrestrial environments. Sedimentology, 33(5), 677-698.

Brown, C.S., M.F. Meier, and A. Post. 1982. Calving speed of Alaska tidewater glaciers, with application to Columbia Glacier. U.S. Geol. Surv. Prof. Pap. 1258-C.

Clapperton, C.M. 1975. The debris content of surging glaciers in Svalbard and Iceland. J. Glaciol., 14(72), 395-406.

Dowdeswell, J.A. and E.K. Dowdeswell. 1989. Debris in icebergs and rates of glaciomarine sedimentation: observations from Spitsbergen and a simple model. $J$. Geol., 97, 221-231.

Dowdeswell, J.A. and D.J. Drewry. 1985. Place names on the Nordaustlandet ice caps, Svalbard. Polar Rec., 22(140), 519-523.

Dowdeswell, J.A., D.J. Drewry, O. Liestøl, and O. Orheim. 1984. Airborne radio echo sounding of sub-polar glaciers in Spitsbergen. Nor. Polarinst. Skr. 182.

Dowdeswell, J.A., D.J. Drewry, A.P.R. Cooper, M.R. Gorman, O. Liestøl, and O. Orheim. 1986. Digital mapping of the Nordaustlandet ice caps from airborne geophysical investigations. Ann. Glaciol., 8, 51-58.

Drewry, D.J. and A.P.R. Cooper. 1981. Processes and models of Antarctic glaciomarine sedimentation. Ann. Glaciol., 2, 117-122.
Drewry, D.J. and O. Liestøl. 1985. Glaciological investigations of surging ice caps in Nordaustlandet, Svalbard, 1983. Polar Rec., 22(139), 359-378.

Elverhøi, A. and A. Solheim. 1983. The physical environment of the western Barents Sea: surface sediment distribution. Nor. Polarinst. Skr. 179A.

Elverhøi, A., Ø. Lønne, and R. Seland. 1983. Glaciomarine sedimentation in a modern fjord environment, Spitsbergen. Polar Res., New Ser., 1(2), 127-149.

Inland Waters Branch. 1969. Glacier atlas of Canada. Ottawa, Department of Energy, Mines and Resources.

Kamb, B., and 7 others. 1985. Glacier surge mechanism 1982-1983 surge of Variegated Glacier, Alaska. Science, 227(4686), 469-479.

Kristensen, M., V.A. Squire, and S.C. Moore. 1982. Tabular icebergs in ocean waves. Nature, 297(5868), 669-671.

Liestø1, O. 1969. Glacier surges in west Spitsbergen. Can. J. Earth Sci., 6(4, Pt. 2), 895-897.

Lunde, T. 1965. Ice conditions at Svalbard 1946-1963. Nor. Polarinst. Arbok 1963, 61-80.

Meier, M.F. and A. Post. 1969. What are glacier surges? Can. J. Earth Sci., 6(4, Pt. 2), 807-817.

Meier, M.F. and A. Post. 1987. Fast tidewater glaciers. J. Geophys. Res., 92(B9), 9051-9058.

Rowan, D.E., T.L. Péwé, R.H. Péwé, and R. Stuckenrath 1982. Holocene glacial geology of the Svea lowland, Spitsbergen, Svalbard. Geogr. Ann., 64A(1-2), 35-51.

Sandford, K.S. 1955. Tabular icebergs between Spitsbergen and Franz Josef Land. Geogr. J., 121(2), 164-170.

Schytt, V. 1969. Some comments on glacier surges in eastern Svalbard. Can. J. Earth Sci., 6(4, Pt. 2), 867 873.

Solheim, A. and S.L. Pfirman. 1985. Sea-floor morphology outside a grounded, surging glacier; Bråsvellbreen, Svalbard. Mar. Geol., 65(1-2), 127-143.

Solheim, A., J.D. Milliman, and A. Elverhøi. 1988. Sediment distribution and sea floor morphology of Storbanken; implications for the glacial history of the northern Barents Sea. Can. J. Earth Sci., 25, 547-556.

Squire, V.A. and S.C. Moore. 1980. Direct measurement of the attenuation of ocean waves by pack ice. Nature, 283(5745), 365-368.

Vinje, T. 1985. The physical environment, western Barents Sea. Drift, composition, morphology and distribution of the sea ice fields in the Barents Sea. Nor. Polarinst. Skr. 179C.

Voigt, U. 1965. Die Bewegung der Gletscherzunge des Kongsvegen (Kingsbay, Vestspitzbergen). Petermanns Geogr. Mitt., 109(1), 1-8.

Voyevodin, V.A. 1972. O razmerakh aysbergov $v$ rayone Zemli Frantsa-Iosifa i Shpitsbergena [Dimensions of icebergs in the region of Franz Josef Land and Spitsbergen]. Probl. Arkt. $i$ Antarkt., 39, 138-140.

Wadhams, P. 1981. The ice cover in the Greenland and Norwegian seas. Rev. Geophys. Space Phys., 19(3), 345-393.

Wadhams, P., M. Kristensen, and O. Orheim. 1983. The response of Antarctic icebergs to ocean waves. $J$. Geophys. Res., 88(C10), 6053-6065. 